\title{
SY 1-1
}

\section{胸腔鏡下肺葉切除術前後における肺葉別呼吸機能の定量的評価}

○吉増 達也!、尾浦 正二?、粉川 庸三?、川後 光正、、平井 慶充?、大橋 拓矢?、清井 めぐみ? 西口 春香?、松谷 雅子?、岡村 吉隆1、中川 克二2、寺田 正樹 ${ }^{2}$

'和歌山県立医科大学第一外科、2和歌山南放射線科クリニック

【はじめに】胸腔鏡下肺葉切除術は開胸手術に比べ呼吸機能温存に有利と考えられる. 我々は CT volumetry を用いて術側と対側に分けて術前後の呼吸機能を測定し, 胸腔鏡下肺葉切除例と開胸肺葉切除例の比較を行っ た.【対象と方法】胸腔鏡下肺葉切除 ( $\mathrm{V}$ 群) 30 例, 開胸肺葉切除 $(\mathrm{O}$ 群) 11 例. 術前後で吸気と呼気の 2 条件で胸部 CT を撮影し肺葉毎に含気量を計算. CT における各肺葉の換気量（LVE）を吸気時と呼気時の 含気量の差として計算. LVEの合計（tLVE）と通常の spirometryの FVC（spFVC）から各肺葉の肺活量 $(\mathrm{LFVC})$ を $\mathrm{LFVC}=\mathrm{spFVC} * \mathrm{LVE} / \mathrm{tLVE}$ として計算.【結果】切除肺葉の LFVCはV 群が $3.02 \pm 0.92 \mathrm{~L}, \mathrm{O}$ 群が $3.02 \pm 0.92 \mathrm{~L} . \quad s p F V C$ は V 群が術前 $3.02 \pm 0.92 \mathrm{~L}$, 術後 $2.73 \pm 0.82 \mathrm{~L}, \mathrm{O}$ 群が術前 $2.86 \pm 0.58 \mathrm{~L}$, 術後 $2.40 \pm$ 0.64L. 両群間で低下率に有意差なし $(\mathrm{p}=0.0575)$. 切除肺葉の LFVC は V 群が $0.62 \pm 0.37 \mathrm{~L}, \mathrm{O}$ 群が $0.49 \pm 0.26$ L で両群間に有意差なし $(\mathrm{p}=0.3182)$. V 群では術側残存肺葉の LFVC が術前 $0.91 \pm 0.32 \mathrm{~L}$ に対し術後 $1.19 \pm$ 0.42L と増加（ $\mathrm{p}<0.0001 ）$ したが, 対側肺葉の LFVC は術前 $1.51 \pm 0.48 \mathrm{~L}$ に対し術後 $1.54 \pm 0.53 \mathrm{~L}$ で差がなかっ た $(\mathrm{p}=0.4104)$. O 群では術側残存肺葉の LFVC は術前 $0.91 \pm 0.34 \mathrm{~L}$, 術後 $0.84 \pm 0.45 \mathrm{~L}$ で差がなかった $(\mathrm{p}=$ $0.4475) ）$ が, 対側肺葉の LFVC は術前 $1.45 \pm 0.29 \mathrm{~L}$ に対し術後 $1.57 \pm 0.34 \mathrm{~L}$ と増加（p=0.0368）がみられた。

【まとめ】肺葉切除術後に残存肺の呼吸機能が代償性に立進することが知られている．この代償性機能充進は 胸腔鏡下肺葉切除術の場合は術側残存肺葉に生じ, 開胸の場合は対側肺葉に生じていることが確認された。 胸壁に対する侵襲度の違いによるものと推測される. 


\section{SY 1-2}

\section{T1 aNOMO 肺癌における葉切除群と区域切除群の術後肺活量 变化の比較}

○森本 淳一、溝渕 輝明、鈴木 秀海、稲毛 輝長、尹 貴正、山本 高義、田中 教久、鎌田 稔子、 中島 崇裕、田川 哲三、岩田 剛和、吉田 成利、吉野 一郎

千葉大学大学院医学研究院呼吸器病態外科学

【背景】区域切除は葉切除より小さい切除範囲で、呼吸機能温存が期待される。区域切除と葉切除後の経時的 肺活量の変化を検討した。【方法】 2009 年 12 月〜2013 年 5 月、手術施行の cT1aN0M0 肺癌手術 120 例中、 術後 6 ケ月以上で葉切群 44 例、区切群 41 例) に関し、FVC および FEV1 の術前、術後 2 か月以内、術後 $2-$ 6 か月、術後 6 か月以上の解析を行った。【結果】術前 $\% F V C$ は葉切群 $99 \pm 13 \%$ 、区切群 $100 \pm 14 \%(\mathrm{p}=0.50)$ 、 術前 $\% F E V 1$ は葉切群 $76 \pm 8.2 \%$ 、区切群 $74 \pm 8.2 （ \mathrm{p}=0.50 ）$ と差はなかった。葉切群の切除葉は右上葉/中葉 /下葉/左上葉/下葉 : 19/4/8/7/6 例、区切群の切除区域は右 $\mathrm{S} 1 / \mathrm{S} 1+\mathrm{S} 6 / \mathrm{S} 2 / \mathrm{S} 2 \mathrm{~b}+\mathrm{S} 3 \mathrm{~b} / \mathrm{S} 3 / \mathrm{S} 6: 2 / 1 / 2 / 1 / 3 / 3$ 例、左 $\mathrm{S} 1+2 / \mathrm{S} 1+2+\mathrm{S} 10 /$ 上区/S3/舌区/S6/S8/S8 $\mathrm{S} 9 / \mathrm{S} 10 / \mathrm{S} 9+\mathrm{S} 10 /$ 底区 : 1/1/10/5/2/4/1/1/1/1/2 例で、 切除亜区域数は葉切群 $8.2 \pm 2.7$ 、区切群 $3.9 \pm 1.7(\mathrm{p}<0.001)$ であった。 FVC 変化率 : (術後 $\mathrm{FVC} \div$ 術前 $\mathrm{FVC}$ ) x $100 （ \%)$ は、術後 2 か月以内では葉切群 $70 \pm 1.8 \%$ 、区切群では $78 \pm 1.9 \% （ \mathrm{p}=0.003 ）$ 、術後2-6 か月では 葉切群 $86 \pm 2.6 \%$ 、区切群 $95 \pm 3.3 \%$ （p=0.04）と区切群で良好だったが、術後 6 か月以上では葉切群 $90 \pm 2.4 \%$ 、 区切群 $93 \pm 2.6 \%(\mathrm{p}=0.40)$ と差が消失した。術後 FEV1 変化率においても術後 2 か月以内では葉切群 $69 \pm$

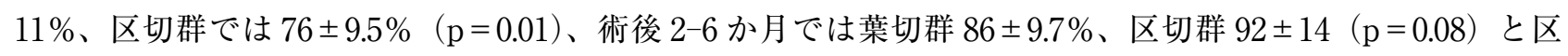
切群が良好であったが、術後 6 か月以上では葉切群 $87 \pm 11 \%$ 、区切群 $90 \pm 12 \% （ \mathrm{p}=0.27 ）$ と同等となった。 【まとめ】区域切除の葉切除に対する肺活量の優越性は、術後 6 力月以上の経過で消失する。肺実質の温存術 式の有用性は総合的な呼吸機能評価が必要と考える。 


\section{SY1-3}

\section{肺葉切除と肺区域切除の術後肺機能と肺血流シンチ SPECT から算出した区域切除後の温存肺葉の肺機能}

○野守 裕明、阿部 大、杉村 裕志、武士 昭彦

亀田総合病院呼吸器外科

[目的］肺区域切除の肺機能温存の利点を明らかにし、さらに肺血流シンチ SPECT 画像を用いて区域切除に おける温存肺葉の一秒量を算出し肺機能温存に対する貢献度を検討した。[方法］ 2012 年 8 月から 2013 年 5 月まで肺葉切除を行った 31 例と肺区域切除を行った 32 例を対象とした。肺葉切除においては右中葉切除と 術前化学放射線照射の症例を除外した。区域切除においては左上区切除を除外した。全例、術前と術後 6 か 月における肺機能検査を受けている。また肺区域切除 12 例において肺血流シンチ SPECT/CT 画像より温存 した各肺葉の一秒量を算出し、術前と術後 6 か月で比較した。さらに除外した左上区切除 3 例において術前 の左上葉と術後温存した舌区の一秒量を算出し、左上区切除の肺機能温存における貢献度を検討した。[結果］ 肺葉切除において一秒量は術前值に対して術後 6 か月は $87 \pm 10 \%$ 、肺区域切除においては $95 \pm 8 \%$ であり、 肺区域切除は肺葉切除より有意に肺機能を温存した（ $\mathrm{p}=0.003 ）$ 。肺血流シンチ SPECT/CT 画像から算出し た一秒量では、区域切除を行った肺葉の一秒量は術前の $0.53 \pm 0.16 \mathrm{~L}$ から術後 6 か月には $0.34 \pm 0.12 \mathrm{~L}$ に低下 し、肺葉の温存率は $66 \pm 16 \%$ 、温存された肺葉の一秒量は全肺一秒量の $15 \pm 7 \%$ に相当した。左上区切除 3

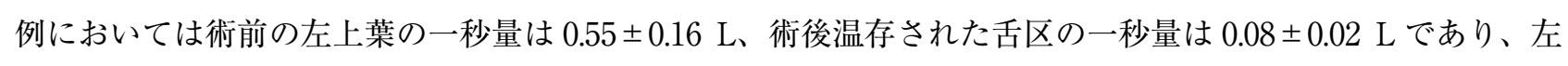
上葉の温存率は $16 \pm 8 \%$ と他の区域切除より有意に低值であった（ $\mathrm{p}=0.028 ）$ 。[結論］肺葉切除は肺区域切 除より肺機能を有意に温存し、それは温存した肺葉の肺機能に依存する。しかし左上区切除においては温存 した舌区の肺機能は低く、肺機能温存を大きくは期待できない。 


\title{
SY 1-4
}

\section{肺区域切除における区域面同定・切離方法による術後呼吸機能 についての検討}

\author{
宮坂 善和、○鈴木 健司、高持 一矢、王 志明
}

順天堂大学医学部呼吸器外科

【背景】近年 GGO を呈するような小型肺癌の報告が増えている。それに伴い早期小型肺癌に対して、区域切 除が標準術式として選択される時代が訪れる可能性がある。【目的】区域切除における重要な要素としての区 域間同定・切離方法の違いが、術後呼吸機能に及ぼす影響を検討する。【対象】 2008 年 2 月〜2013 年 12 月ま で当院で施行した肺区域切除 216 例を対象とした。男性 102 例/女性 114、年齢 24-88 歳（中央值：66 歳） 原発性肺癌 168 例、転移性肺腫瘍 20 例、AAH4 例、その他 24 例。【手術】区域間同定は RSI 法（含気虚脱 法） 181 例、ICG 法（色素注入法） 35 例、区域間切離は自動縫合器 144 例、電気メス 72 例であった。区域切 離面が 1 つであるいわゆる定型区域切除 145 例に対して、切離面が複数ある非定型区域切除が 71 例であっ た。【方法】呼吸機能温存率 $=$ 術後 FEV1/術前 FEV1×100 として、区域同定法、区域切離法、定型/非定型 区域切除、術後胸膜癒着療法の有無で呼吸機能温存率を比較検討した。【結果】術後死亡及び重症合併症はな し。全体の呼吸機能温存率は $87.0 \%$ であり、術後ドレナージ期間 1-34 日（中央值 2 日）であった。術後胸膜 癒着療法を施行した群（11 例）の呼吸機能温存率は $75.9 \%$ であり、施行しなかった群（127 例）の $87.8 \%$ と 比べ有意に低かった。【考察】現時点では当検討において、区域間同定・切離方法、定型・非定型区域切除は いずれも術後呼吸機能温存の観点で許容できる結果となった。しかし術後胸膜癒着療法を施行した群は術後 呼吸機能温存率が低くなる可能性があり、術中の肺瘦閉鎖の徹底が望まれる。 


\title{
SY 1-5
}

\section{肺切除術の呼吸器系インピーダンスに及ぼす影響}

\author{
○浜川 博司'、阪井 宏彰? 、板東 徹 ${ }^{3}$ 、伊達 洋至 ${ }^{4}$

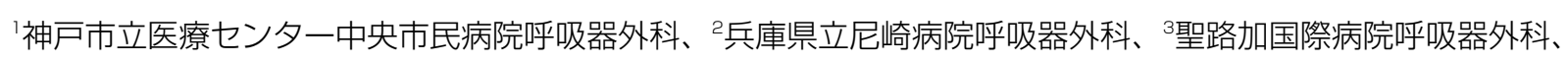 \\ 4京都大学医学部附属病院呼吸器外科
}

[背景］肺切除術後合併症の多くは, 術後早期に生じ, この期間の呼吸機能を術前より予測することは重要で ある. 術後早期には疼痛と強制呼出努力の困難さに影響を受け, Spirometry の值は不確かである.これを補

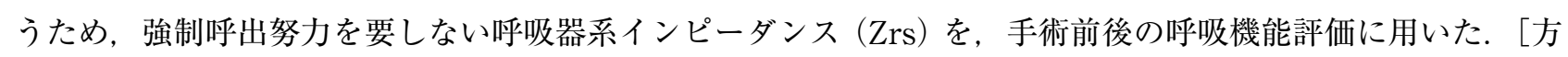
法］肺切除患者データベースより, 基準に適合する 93 例（肺葉切除 51, 区域切除 21 , 部分切除 21 ）をレト ロスペクティブ解析に登録. 切除様式に従い, 解剖学的切除群 (AN 群 = 葉切 + 区切) と非解剖学的切除 (nonAN 群 = 部切）に分類. 術前 CTより切除予定領域を確認し, 予測術後残存肺領域（ppoRA）を計算. ppoRA= (術前全亜区域数一切除亜区域数) /術前全亜区域数. 術前および術後一週間時に, Zrs を測定. Zrsは, $3 \sim 5 \mathrm{~Hz}$ の Pulse Oscillation を自発呼吸に付加し測定. Zrsは, 実数部（Rrs）と虚数部（Xrs）からなる周波数（f）関 数. Zrs $=\mathrm{Rrs}+\mathrm{Xrs}$. 呼吸器系コンプライアンス $(\mathrm{Crs})$ Z Xrs から計算. Crs $=-1 / 2 \pi \mathrm{fXrs} .5 \mathrm{~Hz}$ の Crs $(\mathrm{C} 5)$ は肺容量を反映．X 軸に ppoRA，Y 軸に C5 低下率（術後 C5/術前 C5= post/preC5）をプロットし， AN 群 と nonAN 群の線形回帰直線（y=ax+b）を，共分散分析（ANCOVA）を用いて比較. [結果] 傾き（a）: AN 群 $1.68 \pm 0.181$, nonAN 群 4.81 \pm 1.75 . Y 軸切片 (b) : AN 群 $-0.624 \pm 0.153$, nonAN 群 $-3.79 \pm 1.68$. F = 4.16373, $\mathrm{DFn}=1, \mathrm{DFd}=89, \mathrm{p}=0.044$. [考察] nonAN 群で有意にC5 低下率が大きく, 解剖学的区域に沿 わず切除する場合, 想定される切除領域以上に, 有効な肺換気領域が減少する事が示唆された. 術前 Zrs 測 定により, 術後早期の肺機能予測が可能で, 部分切除より肺葉\&区域切除の方が安静呼吸時の肺換気領域の 減少が少ない事が示された. 


\title{
SY 1-6
}

\section{VO 2 max 測定の代替法としての負荷心電図の有効性の検討}

\author{
○西川 滋人、玉里 滋幸、千原 幸司 \\ 静岡市立静岡病院呼吸器外科
}

【背景と目的】肺切除のリスク評価と適応判断についての ACCP ガイドライン 2013 年版では、全例で $\mathrm{FEV}_{1}$ とDLco を測定、動脈硬化性心血管疾患の合併を意識した循環機能リスク評価を行うこと、予測残存肺機能 不良例では運動負荷試験（階段昇り、 $\mathrm{VO}_{2} \max$ 測定）を行うこと、が記されている。われわれは肺切除の術 前検查として、spirometry と運動耐容能評価と冠動脈疾患合併の有無を検索するため負荷心電図 (Bruce protocol）をルーチンに行い、併存疾患を有する場合や全摘の可能性のある場合には DLco のほか $\mathrm{VO}_{2} \max$ 測定 も行ってきた。人手と時間を要する $\mathrm{VO}_{2} \max$ 測定の代替法として負荷心電図の可能性を検討した。

【対象】 2010 年から 2013 年に $\mathrm{VO}_{2} \max$ 測定と負荷心電図の両方を行った 24 例（肺癌 21 例、COPD に対する 外科治療 3 例)。全て男性で、各指標（肺癌、COPD）の平均值は次の通り。年齢：71 歳、57 歳、 $\mathrm{FEV}_{1}(\mathrm{~L})$ : 1.78、1.23、\% $\mathrm{FEV}_{1}(\%): 76 、 44 、 \mathrm{DLco}^{\prime}(\mathrm{mL} / \mathrm{min} / \mathrm{mmHg}): 10.9 、 11.0$ 。

【方法】 $\mathrm{VO}_{2} \max$ 測定と負荷心電図での血圧 $\times$ 脈拍 $(\mathrm{DP}) 、 \mathrm{VO}_{2} \max$ と負荷心電図での運動持続時間の相関を 検討する。

【結果】負荷心電図と $\mathrm{VO}_{2} \max$ 測定の DP は 14238～38709 の範囲となり、 $\mathrm{y}=1.08 \mathrm{x} \quad(\mathrm{r}=0.64 、 \mathrm{p}<0.01)$ の正 の相関を示した。 $\mathrm{VO}_{2} \mathrm{max}$ と負荷心電図での運動持続時間はそれぞれ 10～ $22 \mathrm{ml} / \mathrm{min} / / \mathrm{kg} 、 105 \sim 540$ 秒の範 囲となり、両者は $\mathrm{y}=0.015 \mathrm{x}+9.98 、 \mathrm{r}=0.76 、 \mathrm{p}<0.01$ の正の相関を示した。

【結語】Bruce protocolによる負荷心電図と $\mathrm{VO}_{2} \max$ 測定検査に扔ける心肺の負荷は同等と考えられ、負荷心 電図運動持続時間は $\mathrm{VO}_{2} \max$ の代替法になる可能性があると思われる。 


\section{SY2- 1}

\section{本邦脳死肺移植 173 例における extended criteria ドナー 肺使用の現状と移植後成績}

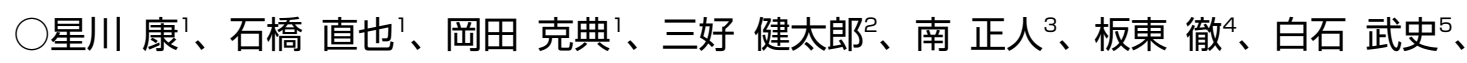
千田 雅之、宮崎 拓郎7、松田 安史?、新井川弘道1、渡邊 龍秋'、佐渡 哲'、野田 雅史? 秋場 美紀、芦㺫 淳太郎8、古川 博之9 $、$ 近藤 丘 $^{1}$

'東北大学加齢医学研究所、2岡山大学、 ${ }^{3}$ 大阪大学、 ${ }^{4}$ 京都大学、5福岡大学、6獨協医科大学、7長崎大学、 ${ }^{8}$ 日本臟器移植ネットワーク、旭川医科大学

2013 年 6 月末までの脳死肺移植 173 例における extended criteria (EC) ドナー肺使用の状況を把握し、EC 肺使用が移植肺生着や術後急性期指標に及ぼす影響を調查することを目的に、日本臟器移植ネットワークに 保存されているドナー情報ファイルから本邦で初めてデータベースを作成し解析作業を行った。173例中最 低 1 つの EC をもつドナー肺が 153 例 (88\%) で用いられていた(EC 数 1，23\%；2，33\%；3，23\%；4，8\%；

$5,2 \%)$ EC の種類と頻度は、気管支液中細菌陽性 103/126 例（82\%）、肺野異常影 91/168 例（54\%）、55 歳以上 $46 / 173(27 \%) 、$ 喫煙指数 400 以上 $34 / 161$ 例（21\%）、膿性痰 26/162 例（16\%）、P/F 比 300 未満 26/ 173 例 (15\%) であった。EC 数ごとの肺生着率曲線を解析した結果、 EC 数 4-5 では EC 数 0-3 群に比し生 着率が有意に低值であった。同様に肺生着率をそれぞれの EC で比較したところ、年齢、膿性痰、喫煙指数 400 で有意差を認めた。レシピエント因子を加えた名義ロジスティックモデル解析では EC 数 4 以上と虚血時間 8 時間超が 1 年以内死亡の独立した危険因子であった。さらに EC 数 4 以上の肺移植例では 3 未満に比し、人 工呼吸期間と ICU 在室期間が長い傾向を認めた。本邦では高い頻度で EC 肺が使用されていること、EC 数 4 以上のドナー肺は予後不良であることが明らかとなった。今後、レシピエントデータベース同様、ドナーデー タベースに関しても共同管理、定期的な更新・解析作業が不可欠と考える。 


\section{SY2-2}

\section{わが国における脳死片肺移植の現状と将来一対側肺合併症自験 例からの考察—}

○南 正人?、井上 匡美?、新谷 康?、中桐 伴行'、舟木 壮一郎?、川村 知裕'、藤原 綾子'、 桃實 徹'、楠本 英則'、木村 亨'、神崎 隆1、野尻 崇'、澤端 章好1、山崎 ひろみ²萩原 邦子²、 奥村 明之進 ${ }^{1}$

'大阪大学呼吸器外科、 ${ }^{2}$ 大阪大学医学部附属病院移植医療部

背景と目的 : 国際心肺移植学会の登録によると肺移植の年間実施症例数は近年増加傾向にあり 3,500 例を超え たが、脳死片肺移植はうち約 1,000 例で、割合は減少し、両肺移植が指向されていることが窑われる。しかし わが国では臟器提供数が未だに極めて少なく、急性期のリスクが大きくない限り専ら提供肺の分配の立場か ら片肺移植が選択されているのが現状である。そこで自験脳死片肺移植例について移植後の対側肺合併症の 観点から検討した。対象：当科の 2000 年から 2013 年までの脳死肺移植（両肺 13 例、片肺 20 例）のうち再 移植を除いた片肺移植 19 例（右 7、左 12)。原疾患はリンパ脈管筋腫症 11、間質性肺炎 6、肺気腫 1、その 他 1 例であった。結果：2 例は悪性腫瘍のため移植後 7 ・4 ヶ月で、 1 例は閉塞性細気管支炎にて移植後 101 ヶ月で死亡した。1 例は移植肺気管支狭乍にて移植後 73 ヶ月で対側再移植となった。しかし 5 年生存率は $83 \%$ であり、両肺移植（74\%）に劣らなかった。特別に治療を必要とした対側肺合併症は、気胸 2 例（ともにリ ンパ脈管筋腫症)、過膨張 1 例 (肺気腫)、感染 2 例（ともに間質性肺炎）（菌球型アスペルギルス症 1 、非結 核性抗酸菌症 1) であった。気胸 1 例で修復術、過膨張 1 例で肺全摘、感染 1 例で肺葉切除を行った。考察： 脳死肺移植術式において、対側肺合併症の観点では可能な限り両肺移植が望ましいものの、現状のレシピエ ント、ドナー数バランスにおいては片肺移植の役割は大きく、当面は対側肺合併症に注意し、手術治療の必 要性も念頭において慎重に管理する必要があると考えられた。 


\section{SY2-3}

\section{当院の特発性間質性肺炎に対する肺移植の現状}

$\bigcirc$ 平塚 昌文、白石 武史、柳澤 純、永田 旭、宮原 聡、徳石 恵太、吉田 康浩、濱武 大輔、 吉永 康照、山下 犋一、岩崎 昭憲

福岡大学病院 呼吸器·乳腺内分泌·小䝨外科

【はじめに】現行の肺レシピエントの選択基準は、疾患の重症度にはよらず、待機期間を優先する事となって いる。特発性間質性肺炎（IIPs）は、待機中死亡率の高い疾患で日本でも待機期間の加算などが検討されて いる。福岡大学では施設の特色上登録疾患の中で IIPs の占める割合が多く待機中死亡率の高さが問題となっ ている。また同疾患は他の移植適応疾患に比べ高齢者が多く術後管理に難渋することも多い。今回当施設で 移植登録をおこなった IIPs 症例を検討した。【対象】肺移植実施施設認定後 8 年間で 40 名の肺移植登録を行っ た。GVHD 関連や薬剤性など特殊型を除外した 21 例の IIPs を解析した。【結果】性別は男性 18 例、女性 3 例、登録時平均年齢は、 52.6 歳 (25〜 59 歳)であった。登録時組織学的確定診断可能であった症例は 7 例 (UIP: 2 例、NSIP : 5 例）であった。その他は画像上診断されており気腫合併肺線維症も 3 例含まれていた。2 1 例 の呼吸器症状発症から登録までに要した平均期間は、78.5 ケ月（6 ケ月～ 22 年）であった。 21 例中 5 例に脳 死片肺移植可能であったが、10 名は登録後待機中に死亡、6 例は現在待機中である。移植となった 5 例の登 録から移植までの平均待機期間は 13.4 ヶ月（4〜27 ケ月）であった。脳死移植となった 5 例中 3 例に移植後、 腎機能障害、感染症（サイトメガロ腸炎、肺化膿症）などの合併症を認めた。【結語】IIPs は待機中死亡率が 高く、高齢の患者が多いため移植後も合併症には注意を要する。IIPs の待機中死亡率を低下させるためには、 診断から登録、待機期間を短縮させる必要があり現在、日本では本疾患に対する待機期間の加算を検討中で ある。 


\section{SY2-4}

\section{当院における肺移植の現況と今後の展望一脳死肺葉移植の可能 性}

○杉本 誠一郎、大藤 剛宏、三好 健太郎、岡田 真典、山本 寛斉、宗 淳一、葉山 牧夫、 山根 正修、豊岡 伸一、三好 新一郎

岡山大学病院呼吸器外科

【背景】藏器移植法の改正後, 脳死肺移植の症例数は着実に増加しているが, 依然として海外に比べて少なく, 現在でも脳死ドナー不足が問題となっている. 特に小览の脳死ドナーの出現は極めて稀なため, 小児の脳死 肺移植は現実的な選択肢ではなく，下葉や中葉を用いた生体肺葉移植が第一選択である。当院では限られた 脳死肺を有効に活用するため, 国内で初めて Ex vivo lung perfusion（EVLP）を臨床応用するなど, マージ ナルドナー肺を積極的に使用しているが, 移植に適さない肺葉をやむを得ず切除して移植を施行する場合も ある. 最近, 海外では脳死肺葉移植としてその有用性が報告されているが, 脳死肺葉移植であればサイズマッ チングする小児や体格の小さいレシピエントが存在するため, 日本でも小児肺移植の新たな解決策となる可 能性がある. 小児に対する脳死肺葉移植の可能性を模索するため, 当院で脳死肺葉移植を施行した症例につ いて検討した.【方法】 1998 年 10 月から 2013 年 11 月までに当院で施行された肺移植 119 例（生体肺移植 70 例, 脳死肺移植 49 例）を retrospective に検討した.【結果】脳死肺移植 49 例中 5 例に脳死肺葉移植を施行 していた，性別は男性 3 例, 女性 2 例で, 年齢中央值は 28 歳 (27-53 歳) で, いずれも両側脳死肺移植であっ た. 切除肺葉は右上葉 1 例, 右下葉 2 例, 左上葉 1 例, 左下葉 1 例で, 切除理由は肺炎 3 例, 肺塞栓 1 例, oversized graft1 例であった. 1 例に EVLP を使用していた. 術後気管支断端瘦の発症はなかった. 生存率で通常 の脳死肺移植や生体肺移植との差はみられなかった、【結論】脳死肺葉移植の成績は良好であり, 小児の脳死 ドナー不足に対する解決策となる可能性がある. 


\section{SY2-5}

\section{肺移植におけるドナー特異的抗体と抗体関連拒絶}

○陳 豊史、高橋 守、大畑 惠資、近藤 健、土屋 恭子、本山 秀樹、山田 徹、佐藤 雅昭、 青山 晃博、板東 徹、毛受 暁史、佐藤 寿彦、園部 誠、大政 貢、大角 明宏、伊達 洋至 京都大学 呼吸器外科

【背景と目的】現在、肺移植における最大の関心事の一つに、抗 HLA 抗体、とくにドナー特異的抗体 (Donor specific antibody:DSA）や抗体関連拒絶（Antibody mediated rejection:AMR）があげられるが、未だ治療 法を含め、国際的にも確立した概念がない。一方、LABSCreeen (One Lambda, CA, USA) の普及とともに、 他臟器の知見が肺移植でも注目され、DSA と AMR、さらには、chronic lung allograft dysfunction (CLAD) への理解に期待がもたれている。今回、当施設でこれまでに経験したDSA についてレトロスペクティブに解 析する。【方法】 2010 年 7 月から 2013 年 9 月までに京都大学で行われた 49 例の肺移植において、術前と術 後定期的にLABScreen を用いて、抗 HLA 抗体の有無とその特定を行った。【結果】術前にDSA（class II） を認めた症例を生体肺移植で 2 例に認めた。MFIが低值で、ダイレクトクロスマッチ陰性であり、肺移植を 施行し、術後 DSA は消失した。術後の de novo DSA は、6 例で認めた。生体肺移植では 3 例（10\%、対グ ラフトでは $6 \%$ )、脳死肺移植では 3 例（17\%）で認めた（対グラフトで $\mathrm{p}=0.11 ）$ 。生体肺移植の症例はすべ て術後 10 か月以上経過後に認め、2 例では CLAD が進行した。脳死肺移植の症例では、全例術後 90 日以内 に出現し、術後 7 か月までには全例消失した。【結論】肺移植において、DSA/AMR や CLADへの理解を深 めるためには、今後も抗 HLA 抗体をモニタリングし解析していくことは重要である。 


\section{SY2-6}

\section{GalT-KO ブタ・カニクイザル間異種肺移植実験の現状一異種 腎臓移植との比較による治療標的の解明と対策}

○佐原 寿史、山田 和彦

鹿児島大学医用ミニブタ・先端医療開発研究センター

【背景・方法】医用動物臟器をドナーとする異種移植は、ドナー臟器不足に対する有力な解決策となる。我々 の研究室では、臨床応用を目指したブタ・サル間異種移植研究として、超急性拒絶反応の標的である $\alpha-G a l$ を発現しない 2 種類の国産 GalT-KO ブタ（MGH GalT-KO 緘維芽細胞の核移植により我々が日本で作出し た MGH 由来 GalT-KO ブタ、および MGH 由来でない非 MGH GalT-KO ブタ）を用い、抗 CD40L 抗体を中 心とする免疫抑制療法を用いた寛容誘導戦略非併用下に、カニクイザルへの異種間腎臓・肺移植を行ってお り、異種腎移植との比較による異種肺移植の課題と対策を検討している。【結果と今後の方針】異種腎移植実 験では、胸腺移植等の免疫寛容誘導性戦略併用下 MGH 由来 GalT-KO ブタ腎移植 3 例では平均 29 日生存し た。一方、異種肺移植実験では、ブタ肺を異種ヒト血液で灌流する ex-vivo モデルや同所性異種左肺移植モ デルによって、GalT-KO ブタ肺が超急性期の肺機能不全を回避しうる結果を得た。しかし異種移植肺は、他 施設論文報告と同様に術後 3 日以内に血栓性微小血管障害による機能不全を呈した。この微小血管障害はド ナーへの一酸化炭素投与により軽減され、一酸化炭素による血管保護効果の重要性が示唆された。異種腎移 植に比べ、異種肺移植では血管内皮性障害に起因する異常炎症・凝固反応によってょり急激な移植肺機能不 全を呈するため、今後、von Willebrand factor、thrombomodulin、CD39 等に着目した、遺伝子導入ブタ開 発を含めた治療方針の改善によって、臨床応用の可能性を高める研究の推進をはかる。 


\section{SY3-1}

\section{悪性胸膜中皮腫に対する胸膜外肺全摘術と放射線療法と化学療 法による集学的治療の成績}

○岡部 和倫、松田 英祐、田尾 裕之、田中 俊樹、高萩 亮宏、林 達朗、吉田 久美子 国立病院機構山口宇部医療センタ一呼吸器外科

【目的】悪性胸膜中皮腫（MPM）に対する胸膜外肺全摘術（EPP）と放射線療法（RT）と化学療法（Chemo） による集学的治療の成績を報告する。

【対象と方法】当院では、2013 年 7 月までの 7 年間に 38 例の EPP を完遂した。3 症例中、演者のチームが 担当した MPM に対する EPP の 34 例を対象とした。当科での MPM に対する治療方法の基本は、EPP、RT、 Chemoの順である。まず EPP を行い、術後約 1 カ月に患側の全胸郭に対する RT を開始する。 RT 終了後 12 力月から CDDP と PEMによるChemoを実施している。本方針で治療した症例が、34 例中 27 例であった。 他の 7 例は導入 Chemo 後に紹介された症例で、EPP と術後 RT の方針とした。生存期間は、手術日から Kaplan-Meier 法で算出した。

【結果】 EPP 時の年齢中央值は、 61 歳 (44-74 歳)。男性 27 例、女性 7 例。右 18 例、左 16 例。上皮型 21 例、 二相型 8 例、肉腫型 2 例、その他 3 例。EPP の手術時間中央值は、 7 時間 16 分 (5 時間 52 分 12 時間 2 分)。 術死は 1 例 $(2.9 \%)$ で、再燃した間質性肺炎の急性増悪のため、術後 14 日に失った。この患者は肉腫型の早 期例で、EPPの 3 カ月前に間質性肺炎に対してステロイドのパルス療法を 2 回受けていた。周術期合併症は、 心房細動が最も多く 10 例（29\%）であった。p-Stageは、IV（腹腔）が 2 例、III が 19 例、II が 6 例、I が 7 例であり、III と IV が $62 \%$ を占めた。45Gy 以上の患側全胸郭への RT は、28 例（82\%）に実施できた。検 討した 34 例の 3 生率は $26 \% 、 2$ 生率は $42 \%$ 、生存期間中央值は 16 カ月であった。

【結語】 EPP とRT と Chemoによる MPM に対する集学的治療は実施可能と判断しているが、更なる治療成 績の向上が望まれる。 


\title{
SY3-2
}

\section{悪性胸膜中皮腫に対する胸膜肺全摘術適応例において予後良好 群の術前予測は可能か?}

\author{
○岩切 章太郎'、深田 武久'、武智 浩子'、阪井 宏彰'、平林 正孝?、糸井 和美' \\ '兵庫県立尼崎病院呼吸器外科、2 兵庫県立尼崎病院呼吸器内科
}

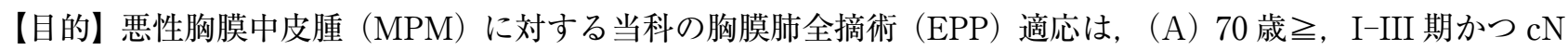
0 かつ胸壁浸潤軽度，上皮 or 二相型，（B）耐術能及び同意あり．今回，EPP の手術適応を明らかにすべく検 討した.【方法】1996/7 月-2013/8 月に胸膜生検術施行し MPM と診断した 172 例のうち（A）を満たす 45 例が対象. 主治療は EPP 又は化学療法 $(\mathrm{Cx})$ で, 術前治療せず術後補助療法施行. 我々は MPM の予後不 良因子を，末梢血好中球/リンパ球比 $\geqq 4, \quad I I I-I V$ 期，非上皮型， PS $\geqq 1$ と報告（胸外総会プレナリー/2013） したが, 今回各例の予後不良因子数を risk score (RS) と規定し, L 群 : RS $\leqq 1, H$ 群 $: \mathrm{RS} \geqq 2$ として検討. 【結果】男 : 女 $=36: 9, \mathrm{I}: \mathrm{II}: \mathrm{III}=11: 13: 21$, 上皮 $:$ 非上皮 $=32: 13,60.7$ 歳（38-70）. EPPtry（A かつ B） は 28 例(完遂 17, 非完遂 11), noEPP(A のみ満たす)は 17 例 (Cx 9, BSC 8). 1/3/5 生率/MST は, EPPtry: $77 \% / 35 \% / 24 \% / 30 \mathrm{~m}, \mathrm{Cx}: 89 \% / 38 \% / 0 \% / 31 \mathrm{~m}, \mathrm{BSC}: 71 \% / 0 \% / 0 \% / 14 \mathrm{~m} . \mathrm{BSC}$ は他 2 群と比べ有意に予後 不良 $(\mathrm{p}=0.022,0.011) . C x$ と EPPtry に有意差は無いが, Cx は最長 $46 \mathrm{~m}$ 生存に対し, EPPtry は 6 例それ 以上生存 (全例完遂，最長 $196 \mathrm{~m}) 。 \mathrm{RS}$ 值による検討では，Cx と比べEPPtry-L 群 $(\mathrm{n}=14): 85 \% / 59 \% / 47 \%$ $/ 55 \mathrm{~m}$ は有意に予後良好（ $\mathrm{p}=0.044 ） に$ 対し，EPPtry $-\mathrm{H}$ 群（ $\mathrm{n}=14 ） ： 69 \% / 9 \% / 0 \% / 15 \mathrm{~m}$ は有意に予後不良 $(\mathrm{p}=0.044)$. EPP 完遂は L 群 $11, \mathrm{H}$ 群 6 と H 群に完遂少ない傾向（ $\mathrm{p}=0.053 ）$ で，予後は L 群 : 90\%/79\%/ 63\%/85m に対し H群：83\%/0\%/0\%/15m，また無再発生存率も L 群：80\%/50\%/40\%/31m に対し H 群： $33 \% / 0 \% / 0 \% / 8 \mathrm{~m}$ で， H 群は有意に予後不良で早期に再発（ $\mathrm{p}=0.0008 ， 0.004)$.【結論】 EPP 完遂は重要だ が, 予後不良因子の複数保有例は EPPtry しても完遂率低く予後不良で, たとえ完遂しても早期再発し予後 不良のため, EPP 適応を慎重に選ぶ必要あり。 


\title{
SY3-3
}

\section{胸膜中皮腫に対する外科治療の検討}

\author{
○西 英行、平山 伸、清水 信義 \\ 岡山労災病院アスベスト疾患ブロックセンター
}

【目的】胸膜中皮腫に対する治療の現状を明らかにし、外科治療の有効性を検討する。【対象】労働者健康福 祉機構のアスベスト関連疾患の研究班により、2007 年〜2013 年 10 月までに全国労災病院より集積された自 経例 141 例を含む 264 例を対象とした。【結果】化学療法（CT）159 例、手術療法（OT） 60 例、放射線療法 （RT）1例、対症療法（BSC）44 例。CT の臨床病期は I/II/III/IV 期が 19/17/78/45 例、OT は 17/20/22/1 例、RT は III 期 1 例。CT の組織型は上皮/二相/肉腫が 101/22/32 例、OT は 41/11/6 例。生存期間中央值 （MST）は、CT/OT/BSC が 12/17/2 か月。Cox 比例ハザードモデルを用いた多変量解析では、臨床病期 I+ II、上皮型、治療、手術が予後因子であった。手術術式の内訳は、胸膜肺全摘術（EPP） 55 例、腫瘍摘出術 (TR) 4 例、胸膜剥皮術 (P/D) 1 例。補助療法は EPP/TR/P/D が 26/3/1 例。EPP の多変量解析では、補 助療法と Pemetrexed を含む化学療法が予後因子であった。当院における手術症例は 43 例であり、EPP39 例、 $\mathrm{P} / \mathrm{D} 2$ 例、TR2 例。補助療法は EPP/TR/P/D が 21/2/2 例。EPP の術後合併症は Clavian-Dindo 分類で、grade I/II/IIIa/IIIb/IVa が 1/33/2/2/1 例で、IIIb は、いずれも右側で気管支断端瘦、IVa も右側で ARDS。術後 30 日 $/ 90$ 日死亡は $0 \% / 2.6 \%$ P/D は、II が 1 例で肺瘻、術死 0 例。 EPP の検討では MST は 45 か月。多変量 解析では、上皮型、病理病期 I + II 期、リンパ節転移が予後因子であった。【結論】上皮型 I+II 期に対する 手術療法が有用であった。現在のところ手術療法では、EPPが主流であるが、術後合併症が多く、 P/D も症 例により選択すべき術式と考えている。しかし、I+II 期症例に対する EPPは、現在のところ有効な術式と 考えている。 


\section{SY3-4}

\section{胸膜中皮腫に対する外科治療の現状と問題点}

○宇佐美 範恭、谷口 哲郎、川口 晃司、福井 高幸、石黒 太志、中村 彰太、尾関 直樹、 山谷 千尋、加藤 毅人、横井 香平 名古屋大学呼吸器外科

【目的】当院での胸膜中皮腫に対する外科治療を含めた集学的治療の成績から、今後解決すべき問題点を検討 する。【対象と方法】2005-2013 年に胸膜肺全摘術（EPP）または胸膜切除/肺剥皮術（PD）を施行した 29 例 を対象とした。予後の点から〈1〉術後 1 年以内死亡例、〈2〉 5 年以上生存例、周術期成績について〈3〉手 術死亡率と合併症率、〈4〉 EPP と PD の比較に関して検討した。【結果】年齢中央値 63 才 (46-73)、男性/女 性 $=26 / 3$ 、臨床病期 $\mathrm{I} / \mathrm{II} / \mathrm{III}=7 / 10 / 12$ 、右 $/$ 左 $=14 / 15$ 、術前化学療法有 $/$ 無 $=19 / 10$ であった。術式は $\mathrm{EPP} / \mathrm{PD}$ /Extended $\mathrm{PD}=22 / 1 / 6$ 、病理病期 $\mathrm{I} / \mathrm{II} / \mathrm{III} / \mathrm{IV}=1 / 5 / 18 / 5$ 、組織型は上皮/二相/肉腫 $=20 / 8 / 1$ であった。全 体の 1 生率 $62 \%$ 、 5 生率 $26 \%$ 、無再発 1 生率 $59 \%$ 、再発症例に扔ける再発後 1 生率は $30 \%$ であった。〈1〉術 後 1 年以内に死亡した 9 例は、全例 EPP かつ男性で病理病期 III 期以上であった。また右側手術と合併症率、 術後在院日数に有意差を認めた。〈2〉 5 年以上生存例は EPP の 2 例で、いずれもアスベスト暴露歴のない女 性で、術後 3 年目に遠隔再発を認めたが、その後化学療法を受け担癌生存している。〈3〉手術死亡率 $3.4 \%$ 、 合併症は Grade3 以上が $35 \%$ で認められた。〈4〉 EPP と PD で手術時間や出血量に有意差なし。合併症、手 術死亡、術後在院日数も有意差はないが、PDの方が少ない傾向はみられた。【考察】手術を含む集学的治療 が奏効する症例を適確に選択することが必要である。手術自体の安全性については許容される範囲に到達し ているが、PD の低侵襲性を害感できていない。今後はPD の手技安定化、中長期予後を検討し、MCR を得 るための手段として EPP と PD を使い分けできるようになることが重要と考える。 


\section{SY3-5}

\section{眴膜切除/肺剥皮術を企図した悪性胸膜中皮畽の治療戦略}

○宮田 義浩、吉屋 智晴、見前 隆洋、笹田 伸介、三隅 啓三、坪川 典史、岡田 守人 広島大学原医研腫瘍外科

【方法】当科では切除可能悪性胸膜中皮腫（MPM）に対しては術前化学療法後に、2011 年 7 月までは胸膜肺 全摘（EPP）を、それ以降は臟側胸膜の完全剥離切除が可能な症例は根治的胸膜切除/肺剥皮術 $(\mathrm{P} / \mathrm{D})$ を行 い、術中剥離困難と判断すれば $\mathrm{EPP}$ を選択している。P/D 後には術後単剂化学療法を、EPP 後には IMRT を追加した。当科に扔ける $\mathrm{P} / \mathrm{D}$ を企図した治療戦略について検討した。【結果】 2007 年 4 月から 2013 年 10 月までに術前療法後に手術を行った MPM は 37 例、内 14 例を $\mathrm{P} / \mathrm{D}$ を企図して行った。 $\mathrm{P} / \mathrm{D}$ 可能であった症 例は 6 例、EPP は 6 例、完全切除不能 2 例。P/D 群、EPP 群の背景因子は年齢 65.5/65.8、男性 6/6、右 3/4、 上皮型 6/4、cN2 0/2、EPP をした場合の術後予測 1 秒量 1413/1445、患側血流割合 27.4/33.7、化学療法効果 radiologic PR 以上 $3 / 3 、 P E T$ による metabolic PR 以上 $3 / 3$ であった。EPP の 6 例は全例 $\mathrm{P} / \mathrm{D}$ を試みたが、 3 例で臓側胸膜の肥厚が高度で剥離困難、3 例では臓側胸膜が菲薄なため完全剥離が困難であり、いずれも術 中に EPP に移行した。手術時間 635/508、出血量 3885/2790、手術関連死亡はないものの、術後合併症は $\mathrm{P} /$ $\mathrm{D}$ では肺漏の遷延 $2 、 \mathrm{EPP}$ では膿胸 1 を認めた。 $\mathrm{EPP}$ 例の病理検索では肉眼的に腫瘍が明らかでない範囲に も、顕微鏡的腫瘍が存在し、また顕微鏡的腫瘍が存在しないことを術中に把握するのは困難であった。2 年 生存率 $87.5 \% / 59.1 \% 、 \mathrm{P} / \mathrm{D}$ の再発・死亡は 1 例のみであり、3 例が 2 年以上無再発生存中である。【結語】症 例を選べば $\mathrm{P} / \mathrm{D}$ でも一定の予後が得られる可能性がある。 


\section{SY3-6}

\section{EPP 術後再発に対して、抗癌剮治療は遂行可能かつ有効であ る}

○多久和 輝尚'、中村 晃史'、黒田 鮎美'、橋本 昌樹'、松本 成司'、近藤 展行'、坪田 紀明'、 田端 千春²、中野 孝司 ${ }^{2} 、$ 長谷川 誠紀'

'兵庫医科大学呼吸器外科、㚱兵庫医科大学呼吸器 $R C U$ 科

【背景】EPP はその過大な手術侵襲のため再発後に十分な抗癌剂治療ができないと言われ、局所制御効果で は $\mathrm{P} / \mathrm{D}$ に優る $\mathrm{EPP}$ が生存率では $\mathrm{P} / \mathrm{D}$ を越えない理由の 1 つはこの点であると信じられている。【目的】 $\mathrm{EPP}$ 術後再発に対する全身化学療法の遂行可能性およびその治療効果を検討する。【対象】 2013 年 11 月までに導 入化学療法後に EPP を完遂し 56 例（EPP 後 RT 有り 34 例、RT 無し 22 例）を対象とする。【結果】 EPP 後 再発は 31 例。手術時年齢平均 60 歳 (37-70)、男性/女性 $=25 / 6$ 、病理病期 I/II $/ \mathrm{III} / \mathrm{IV}=1 / 5 / 22 / 3$ 、 EPP 後 $\mathrm{RT}$ 有り $/$ 無し $=19 / 12$ 、右/左 $=11 / 20$ であった。 EPP 後無再発期間は 8.9 か月 $(\mathrm{RT}$ 有り 12 か月、 RT 無し 5.5 か月）であった。再発後治療は BSC（best supportive care）が 13 例（42\%）、18例（58\%）に full doseの 抗癌剂治療 $(\mathrm{GEM}+\mathrm{CPT} 11, \mathrm{CBDCA}+\mathrm{NVB}, \mathrm{CBDCA}+\mathrm{PEM}, \mathrm{CDDP}+\mathrm{PEM}, \mathrm{MTX}+\mathrm{CPT} 11$ + DXR, CDDP + CPT11+DXR，PEM，MTX，GEM）3 コース以上を実施した。再発後生存期間（中央值）は BSC 群で 3 ヶ 月、full dose 化学療法群で 22 ヶ月であった。【結論】 EPP を含む bi-/trimodality therapy 後再発に対して約 6 割の症例で全身化学療法が実施可能であった。再発後 BSC 群に比較して再発後全身化学療法群で著明な生 存期間延長（3 ケ月vs 22 ケ月）が認められた。 